\title{
Hubungan Peran Kepala Ruangan dan Supervisor Keperawatan dengan Motivasi Perawat dalam Melakukan Dokumentasi Keperawatan
}

\author{
Peggy Passya $^{1}$, Ichsan Rizany ${ }^{2 *}$, Herry Setiawan ${ }^{3}$ \\ 1,2,3Program Studi Ilmu Keperawatan, Fakultas Kedokteran, Universitas Lambung \\ Mangkurat, Banjarbaru, Indonesia \\ *ichsan.r.psik@ulm.ac.id
}

\begin{abstract}
Good nursing documentation is inseparable from nurse motivation. Motivation of nurses is influenced internally and externally, one of them through the role of the head nursee and nurse supervisor To find out the relationship between the role of head nurses and nurse supervisor with the motivation of nurses in carrying out nursing documentation at Idaman Hospital in Banjarbaru City. The research used correlational study with a cross sectional approach and probability sampling technique with a type of simple random sampling. The sample in the study were 67 nurses in the inpatient room of Idaman Hospital, Banjarbaru City. Data retrieval was done by giving a questionnaire. Test analysis used Pearson correlation. The results of the study showed an average head role of 51.10, room supervisors averaged 32.81 and nurses' motivation averaged 33.61. These results indicate the head nurse and nurse supervisor often perform their roles and motivation of nurses is high. The results of the analysis found a positive relationship between the role of the head nurse and nurses' motivation in conducting nursing documentation in Idaman Hospital in Banjarbaru City ( $p$ Value $=\langle 0001 ; 95 \%$ CI) and there was a positive relationship between the role of room supervisor and nurse motivation in conducting nursing documentation at RSD Idaman Banjarbaru City ( $p$ Value $=\langle 0001 ; 95 \% C I)$. The role of the head nurse and the supervisor of the room can influence the level of motivation of nurses in conducting nursing documentation so that the head nurse and nurse supervisor are expected to perform their roles well.
\end{abstract}

Keywords: nursing documentation, nurse motivation, role of head nurse, nurse supervisor

\begin{abstract}
Abstrak
Dokumentasi keperawatan yang baik tidak terlepas dari motivasi perawat. Motivasi perawat dipengaruhi secara internal dan eksternal salah satunya melalui peran kepala ruangan dan superisor ruangan. Mengetahui hubungan peran kepala ruangan dan supervisor ruangan dengan motivasi perawat dalam melakukan dokumentasi keperawatan di RSD Idaman Kota Banjarbaru. Metode penelitian bersifat korelasi dengan desain cross sectional dan teknik sampel probability sampling dengan jenis simple random sampling. Sampel pada penelitian ada 67 perawat pelaksana di ruang rawat inap RSD Idaman Kota Banjarbaru. Pengambilan data dilakukan dengan kuesioner. Uji analisis menggunakan korelasi pearson. Hasil penelitian menunjukan gambaran skor peran kepala ruangan rata-rata sebesar 51,10 dan rata-rata peran supervisor ruangan sebesar 32,81, artinya peran kepala ruangan dan supervisor dijalankan dengan optimal. Sedangkan rata-rata motivasi perawat sebesar 33,61 (motivasi perawat tinggi). Hasil analisis didapatkan adanya hubungan yang positif antara peran kepala ruangan dengan motivasi perawat dalam melakukan dokumentasi keperawatan di RSDI Kota Banjarbaru ( $p$ Value = $<0001 ; 95 \% C I)$ dan ada hubungan positif antara peran supervisor ruangan dengan motivasi perawat dalam melakukan dokumentasi keperawatan di RSDI Kota Banjarbaru ( $p$ Value $=<0001 ; 95 \% C I)$. Peran kepala ruangan dan supervisor ruangan dapat mempengaruhi tingkat motivasi perawat dalam melakukan dokumentasi keperawatan maka diharapkan kepala ruangan dan supervisor ruangan dapat menjalankan perannya dengan baik.
\end{abstract}

Kata Kunci: dokumentasi keperawatan, motivasi perawat, peran kepala ruangan, supervisor keperawatan 


\section{PENDAHULUAN}

Rumah Sakit sebagai tempat pelayanan kesehatan memiliki banyak profesi yang akan membentuk satu kesatuan, dan mayoritas tenaga kesehatan yang ada adalah perawat (Wang 2010; Suara 2010). Perawat memiliki tanggung jawab berupa dokumentasi keperawatan yang digunakan sebagai bukti kinerja perawat dalam memberikan pelayanan keperawatan kepada pasien dan dapat digunakan sebagai tanggung gugat perawat (Bara \& Suryati, 2014; Green \& Thomas, 2008).

Kinerja perawat dalam pendokumentasian asuhan keperawatan tidak terlepas dari motivasi perawat sendiri. Motivasi merupakan pendorong seseorang untuk bergerak mencapai tujuan (Marquis \& Huston, 2010). Motivasi dipengaruhi secara intrinsik dan ekstrinsik. Faktor intrinsik meliputi prestasi, pengakuan dan penghargaan, tugas itu sendiri dan kewajiban sebagai perawat. Faktor ekstrinsik meliputi gaji/imbalan, jaminan keamanan dan kesehatan, tunjangan, kondisi kerja, kebijakan rumah sakit, hubungan antar pribadi dan reward dari atasan (Gitosudarmo, 2012; Robbins, 2015). Selain dua faktor diatas ada faktor lain yang mempengaruhi motivasi yaitu peran kepala ruangan dan supervisor ruangan (Marquis \& Huston, 2010).

Kepala ruangan dan supervisor ruangan sangat berperan dalam memotivasi perawat pelaksana dengan adanya perencanaan yang matang dan arahan yang benar kepada perawat pelaksana (Nivalinda, 2013). Kepala ruangan memiliki sepuluh peran yang kemudian dikelompokkan menjadi tiga peran. Peran kepala ruangan yang dimaksud yaitu peran hubungan antar pribadi, peran informasi, dan peran keputusan (Robbins, 2015). Supervisor juga memiliki peran penting dalam menjalankan tugasnya. Peran supervisor adalah sebagai mentoring, power perspective, dan networking (Sitorus \& Panjaitan, 2011).

Adapun dampak apabila peran kepala ruangan tidak dilaksanakan dengan baik maka akan terjadi penurunan pelayanan kesehatan, penurunan motivasi karyawan, penurunan skill atau kemampuan karyawan, kurang kedisiplinan karyawan, kurangnya informasi aktual dan terupdate dari luar atau dalam organisasi, tidak terorganisirnya sumber daya yang ada, dan terjadi kesulitan dalam pemecahan masalah (Robbins, 2015). Dampak apabila peran supervisor tidak dilaksanakan dengan baik adalah hubungan dalam melakukan proses keperawatan akan lemah, menurunnya motivasi kerja karyawan dan menurunnya komitmen karyawan terhadap mutu pelayanan kesehatan (Sitorus \& Panjaitan, 2011).

Hasil kajian praktek klinik keperawatan melalui praktik profesi ners tahun 2018, terkait dokumentasi keperawatan di RSD Idaman Kota Banjarbaru sudah baik secara kelengkapan tetapi masih terdapat kekosongan pada pengisian rekam medis pasien. Berdasarkan hasil observasi rekam medis terdapat data pengkajian yang tidak terisi di beberapa status pasien dan persentase kelengkapan diagnosa keperawatan sebesar $63.89 \%$, perencanaan $51,33 \%$. Evaluasi keperawatan ditemukan masih ada beberapa ketidak sesuaian antara diagnosa yang diangkat dengan pengkajian lembar diagnosa yang di lampirkan di buku status. 
Studi pendahuluan yang dilakukan peneliti melalui wawancara kepada beberapa perawat diruang rawat inap RSD Idaman Kota Banjarbaru didapatkan hasil beberapa perawat pelaksana mengalami penurunan motivasi pendokumentasian keperawatan pada malam hari dikarenakan jumlah perawat yang minimum pada malam hari dan kelelahan sehingga di sela waktu perawat memilih tidur kembali ketika selesai melakukan tindakan dan menunda pendokumentasian. Penelitian ini bertujuan untuk menilai bagaimana hubungan peran kepala ruangan dan supervisor ruangan dengan motivasi perawat dalam melakukan dokumentasi keperawatan di RSD Idaman Kota Banjarbaru.

\section{METODE}

Berdasarkan definisi operasional peran kepala ruangan adalah Sudut pandang perawat terhadap tingkah laku yang diharapkan dimiliki kepala ruangan dalam pelaksanaan dokumentasi keperawatan. Peran supervisor ruangan adalah Sudut pandang perawat terhadap tingkah laku yang diharapkan dimiliki supervisor ruangan dalam pelaksanaan dokumentasi keperawatan.

Desain penelitian yang digunakan adalah cross sectional. Pupulasi pada penelitian adalah 117 perawat pelaksana di ruang rawat inap RSD Idaman Kota Banjarbaru. Teknik sampling pada penelitian adalah probability sampling dengan jenis simple random sampling. Jumlah sampel pada penelitian adalah 67 perawat sesuai kriteria inklusi dan perhitungan dengan rumus uji hipotesis populasi mean (two sided test) S.K.Lawangan dan S.Lameshow. Sampel diambil dari 6 ruang rawat inap, 1 ruang bedah, 2 ruang penyakit dalam, 2 ruang anak, 1 ruang VIP. Kriteria inklusi yang dimaksud adalah perawat pelaksana ruang rawat inap RSD Idaman Kota Banjarbaru, bersedia menjadi responden, perawat minimal DIII. Kriteria eksklusi yang dimaksud adalah perawat yang tidak lengkap dalam pengisian kuesioner dan perawat yang tidak hadir saat penelitian.

Instrumen yang digunakan pada penelitian adalah kuesioner karakteristik responden, peran kepala ruangan, peran supervisor ruangan dan motivasi perawat. Pembaca dapat mengetahui tentang kuesionernya karena ada petunjuk pengisian pada halaman pertama dan peneliti juga menjelaskan tentang pengisian kuesioner tersebut. Kuesioner peran kepala ruangan dikembangkan oleh peneliti berdasarkan buku Robbins SP 2015 terdiri dari 16 pernyataan dengan hasil uji valid 0,363 0,638 dan nilai relibilitas sebesar 0,819. Kuesioner peran supervisor ruangan dikembangkan oleh peneliti berdasarkan buku Sitorus R dan Panjaitan R (2011) yang terdiri dari 10 pernyataan dengan hasil uji valid 0,373-0,503 dan nilai relibilitas sebesar 0,759. Kuesioner motivasi perawat dikembangkan oleh peneliti berdasarkan buku Gitosudarmo (2012) dan Robbins (2015) yang terdiri dari 11 pernyataan dengan hasil uji valid 0,370-0,569 dan nilai relibilitas sebesar 0,770. Keterangan uji validitas dan reliabilitas instruen yang digunakan adalah 0,361 .

Analisis data menggunakan uji korelasi pearson. Prinsip etik yang diperhatikan dalam penelitian adalah persetujuan, tanpa nama, kerahasiaan, hak untuk menolak dan berbuat baik. Penelitian ini telah dinyatakan layak etik dari Fakultas Kedokteran dengan No. 1081/KEPK-FK UNLAM/EC/XII/2018. 
HASIL

Tabel 1. Rata-rata Karakteristik Responden Menurut Umur, Masa Kerja dan Penghasilan $(n=67)$

\begin{tabular}{llll}
\hline \multicolumn{1}{c}{ Variabel } & Mean & \multicolumn{1}{c}{ Min-Max } & \multicolumn{1}{c}{$S D$} \\
\hline $\begin{array}{l}\text { Umur } \\
\text { (Tahun) }\end{array}$ & 29,40 & $22-42$ & 4,834 \\
$\begin{array}{l}\text { Masa Kerja } \\
\text { (Tahun) }\end{array}$ & 5,67 & $1-18$ & 4,147 \\
$\begin{array}{l}\text { Penghasilan } \\
\text { (Rp) }\end{array}$ & 1.658 .58 & $1.200 .000-$ & $752.400,10$ \\
\hline
\end{tabular}

Tabel 1. menunjukan rata-rata umur responden adalah 29,40 tahun dengan umur termuda perawat adalah 22 tahun dan tertua umur perawat adalah 42 tahun. Rata-rata masa kerja responden adalah 5,67 tahun dengan masa kerja paling rendah responden adalah 1 tahun dan masa kerja paling lama responden adalah 18 tahun. Rata-rata penghasilan responden adalah $\mathrm{Rp}$. 1.658.582,09 dengan penghasilan terenda responden adalah Rp. 1.200 .000 dan penghasilan tertinggi responden adalah $\mathrm{Rp}$. 5.000.000. Penghasilan yang didapat merupakan gaji tetap sebagai seorang perawat di RSD Idaman Kota Banjarbaru. Penghasilan didapatkan dari gaji pokok sebagai perawat namun ada perawat yang mendapatkan gajih minimal sesuai dijelaskan ditabel karena perawat masih baru dan ada yang mendapatkan gaji dengan nilai maksimal sesuai tabel karena sudah lama bekerja sebagai perawat.
Tabel 2. Distribusi Karakteristik Responden Menurut Jenis Kelamin, Pendidikan dan Jenjang Karir (n=67)

\begin{tabular}{lcc}
\hline Variabel & $\mathrm{n}$ & $\%$ \\
\hline Jenis Kelamin & & \\
Perempuan & 24 & 35,8 \\
Laki-laki & 43 & 64,2 \\
Pendidikan & & \\
DIII & 48 & 71,6 \\
S.Kep. & 3 & 4,5 \\
Ners & 16 & 23,9 \\
Jenjang Karir & & \\
PK I & 45 & 67,2 \\
PK II & 21 & 31,3 \\
PK III & 1 & 1,5 \\
\hline
\end{tabular}

Tabel 2. menunjukan data lebih banyak responden berjenis kelamin perempuan $64,2 \%$ dibandingkan responden berjenis kelamin laki-laki 35,8\%. Pendidikan menggambarkan data terbanyak pendidikan responden adalah DIII $71,6 \%$ dan data terendah pendidikan responden adalah S.Kep 4,5\%. Jenjang karir menggambarkan bahwa data terbanyak didapatkan dari responden yang memiliki jenjang karir (PK1) 67,2\% dan data terendah diperoleh dari responden yang memiliki jenjang karir PK3 1,5\%. Responden menjelaskan bahwa mereka masih banyak yang berjenjang karir PK1 dikarenakan masih belu adanya kesempatan untuk menjadi Perawat Klinis lebih tinggi meski mereka cukup lama bekerja. 
Tabel 3. Interpretasi Peran Kepala Ruangan di RSD Idaman Kota Banjarbaru Berdasarkan Persepsi Perawat (N=67)

\begin{tabular}{cccc}
\hline Mean & Median & Min-Max & SD \\
\hline 51,10 & 51,00 & $33-64$ & 6,736 \\
\hline
\end{tabular}

Tabel 3. menunjukan nilai rata-rata peran kepala ruangan di RSD Idaman Kota Banjarbaru sebesar 51,10 dengan nilai terendah 33, nilai tertinggi 64 dan standar deviasi 6,736. Ketika dipresentasikan menjadi $79,84 \%$ dari $100 \%$ skor pernyataan.

Tabel 4. Interpretasi Peran Supervisor Ruangan di RSD Idaman Kota Banjarbaru Berdasarkan Persepsi Perawat $(n=67)$

\begin{tabular}{cccc}
\hline Mean & Median & Min-Max & SD \\
\hline 32,81 & 33,00 & $24-40$ & 3,722 \\
\hline
\end{tabular}

Tabel 4. menunjukan nilai rata-rata peran supervisor ruangan di RSD Idaman Kota Banjarbaru sebesar 32,81 dengan nilai terendah 24, nilai tertinggi 40 dan standar deviasi 3,722. Ketika dipresentasikan menjadi $82,01 \%$ dari $100 \%$ skor pernyataan.

Tabel 5. Interpretasi motivasi perawat dalam melakukan dokumentasi keperawatan di RSD Idaman Kota Banjarbaru (n=67)

\begin{tabular}{cccc}
\hline Mean & Median & Min-Max & SD \\
\hline 33,61 & 34.00 & $24-40$ & 3,307 \\
\hline
\end{tabular}

Tabel 5 menunjukan nilai rata-rata motivasi perawat dalam melakukan dokumentasi keperawatan di RSD Idaman Kota Banjarbaru sebesar 33,61 dengan nilai terendah 24, nilai tertinggi 40 dan standar deviasi 3,307. Ketika di presentasekan menjadi $76,38 \%$ dari $100 \%$ skor pernyataan.
Tabel 6. Hubungan Peran Kepala Ruangan dengan Motivasi Perawat dalam

Melakukan Dokumentasi Keperawatan di RSD Idaman Kota Banjarbaru $(n=67)$

\begin{tabular}{lcc}
\hline Variabel & p-value & \multicolumn{2}{c}{ Koefisien Korelasi(r) } \\
\hline $\begin{array}{l}\text { Peran Kepala } \\
\text { Ruangan }\end{array}$ & 0,000 & 0,645 \\
Motivasi Perawat & & \\
\hline
\end{tabular}

Tabel 6. menunjukan hubungan peran kepala ruangan dengan motivasi perawat dalam melakukan dokumentasi keperawatan di RSD Idaman Kota Banjarbaru dari 67 responden didapatkan nilai signifikan peran kepala ruangan dengan motivasi perawat sebesar $(\mathrm{p}=0,000)$. Hasil analisis di dapatkan $\mathrm{p}$ value $<0,001$ dan koefisien korelasi (r) sebesar 0,645 maka $\mathrm{H}_{\mathrm{o}}$ ditolak yang memiliki arti ada korelasi/ada hubungan signifikan antara peran kepala ruangan dengan motivasi perawat dalam melakukan dokumentasi keperawatan di RSD Idaman Kota Banjarbaru dengan hubungan yang kuat dan hubungan mengarah positif yang artinya semakin sering peran kepala ruangan dirasakan perawat maka semakin tinggi motivasi perawat dalam melakukan dokumentasi keperawatan sebaliknya apabila semakin jarang peran kepala ruangan dirasakan perawat maka semakin rendah motivasi perawat dalam melakukan dokumentasi keperawatan.

Tabel 7. Hubungan Peran Supervisor Ruangan dengan Motivasi dalam Melakukan Dokumentasi Keperawatan di RSD Idaman Kota Banjarbaru (N=67)

\begin{tabular}{lcc}
\hline Variabel & $p$-value & Koefisien Korelasi(r) \\
\hline $\begin{array}{l}\text { Peran } \\
\begin{array}{l}\text { Supervisor } \quad 0,000 \\
\text { Motivasi Perawat }\end{array}\end{array}$ \\
\hline
\end{tabular}

Tabel 7 menunjukan hubungan peran supervisor ruangan dengan motivasi 
perawat dalam melakukan dokumentasi keperawatan di RSD Idaman Kota Banjarbaru dari 67 responden didapatkan nilai signifikan peran supervisor ruangan dengan motivasi perawat sebesar $(\mathrm{p}=0,000)$. Hasil analisis di dapatkan $\mathrm{p}$ value $<0,001$ dan koefisien korelasi (r) sebesar 0,500 maka $\mathrm{H}_{\mathrm{o}}$ ditolak yang memiliki arti ada korelasi/ada hubungan signifikan antara peran supervisor ruangan dengan motivasi perawat dalam melakukan dokumentasi keperawatan di RSD Idaman Kota Banjarbaru dengan kekuatan hubungan sedang dan arah hubungan positif yang artinya semakin tinggi peran supervisor di ruangan maka semakin tinggi motivasi perawat dalam melakukan dokumentasi keperawatan sebaliknya apabila semakin jarang peran supervisor ruangan dirasakan perawat maka semakin rendah motivasi perawat dalam melakukan dokumentasi keperawatan.

\section{PEMBAHASAN}

\section{Peran Kepala Ruangan di RSD Idaman Kota Banjarbaru}

Penelitian Warsito (2006) menunjukan peran kepala ruangan dalam memberi arahan, memberikan motivasi kepada perawat, memberikan pujian kepada perawat, dan memberi bimbingan kepada perawat sangat penting dalam pelaksanaan dokumentaasi keperawatan dengan peningkatan motivasi perawat. Penelitian serupa dilakukan oleh Wahyuni (2007) koordinasi yang dilakukan kepala ruangan merupakan bentuk keselarasan segala tindakan antar tenaga kesehatan di rumah sakit. Koordinasi ini bertujuan meningkatkan perasaan tanggung jawab, menambah perasaan peduli dan menciptakan kerjasama yang baik sehingga berefek pada peningkatan motivasi kerja perawat.

\section{Peran Supervisor Ruangan di RSD Idaman Kota Banjarbaru}

Penelitian yang dilakukan Fazriannor (2018) menjelaskan perawat memiliki persepsi baik terhadap arahan yang diberikan supervisor sebanyak 95,5\% dan persepsi kurang baik $4,5 \%$ karena perawat merasa jarang mendapatkan arahan dari supervisor. Hal ini diperkuat oleh teori dari Sitorus \& Panjaitan (2011) yang menjelaskan pentingnya peran supervisor ruangan dalam memberi arahan serta pelatihan guna mengembangkan kinerja perawat serta berperan aktif mengajarkan perawat dalam pelayanan kesehatan.

\section{Motivasi Perawat dalam Melakukan Dokumentasi Keperawatan di RSD Idaman Kota Banjarbaru}

Penelitian yang sejalan dilakukan oleh Fazriannor (2018) menjelaskan motivasi merupakan salah satu hal yang meningkatkan rasa tanggung jawab seorang perawat dalam menyelesaikan tugas yang diberikan. Berdasarkan penelitian Hasniah (2013) menjelaskan bahwa motivasi tinggi yang dimiliki perawat akan berdampak baik pada kinerja perawat dalam melakukan dokumentasi keperawatan, sebaliknya motivasi rendah yang dimiliki perawat akan berdampak buruk pada kinerja perawat dalam melakukan dokumentasi keperawatan. Hal ini sesuai dengan teori yang dismpaikan oleh Triwibowo (2013) yang menjelaskan motivasi sebagian dari kekuatan atau dorongan sesorang untuk mencapai suatu prestasi yang dipengaruhi oleh faktor internal dan eksternal. 


\section{Hubungan Peran Kepala Ruangan Ruangan dengan Motivasi Perawat dalam Melakukan Dokumentasi Keperawatan di RSD Idaman Kota Banjarbaru}

Hasil penelitian ini sesuai pada teori yang disampaikan Robbins (2015) apabila kepala ruangan tidak menjalankan perannya maka akan terjadi penurunan motivasi kerja perawat, penurunan skill atau kemampuan perawat, kurang disiplin, kurang informasi terupdate, tidak terorganisisrnya sumber daya yang ada serta kesulitan dalam pemecahan masalah. Penelitian yang serupa dilakukan oleh Yanti (2013) menunjukan hasil ada hubungan antara motivasi dan supervisi kepala ruangan dengan kualitas dokumentasi asuhan keperawatan. Peran kepala ruangan atau supervisi dari kepala ruangan sangat menunjang perbaikan dokumentasi keperawatan dengan meningkatkan motivasi kerja perawat.

Penelitian dari Rizany (2018) menyebutkan perawat memerlukan kesempatan melakukan pelatihan maupun program pengajaran dari seorang manajer dalam upaya meningkatkan kompetensi perawat. Namun, penelitian yang dilakukan Purnomo (2016) tidak sejalan dengan hasil yang didapatkan peneliti. Purnomo (2016) menjelaskan bahwa tidak ada hubungan signifikan antara supervisi kepala ruangan dengan kelengkapan dokumentasi keperawatan. Peran yang kurang dari kepala ruangan tidak mempengaruhi kelengkapan dokumentasi keperawatan. Penelitian yang dilakukan oleh Baljoon (2018) menyebutkan bahwa pengawasan, pemberdayaan, tunjangan, hubungan interpersonal dan reward yang diberikan oleh kepala ruangan mempengaruhi tingkat motivasi kerja perawat. Hasil penelitian dari Kamanzi dan Nkosi (2011) menjelaskan beberapa responden mengatakan bahwa kondisi kerja, pengakuan, penghargaan, reward, pengawasan, tunjangan serta peran dari manajemen memotivasi perawat dalam meningkatkat kinerja perawat. Hasil penelitian Hoonakker et al (2013) menjelaskan bahwa dukungn dari manajemen serta hubungan interpersonal mempengaruhi motivasi perawat dalam melakukan pekerjaan. Oleh karena itu, peran kepala ruangan berupa pengawasan, hubungan interpersonal, reward serta dukungan dapat meningkatkan motivasi kerja perawat terutama dalam melakukan dokumentasi keperawatan.

\section{Hubungan Peran Supervisor Ruangan dengan Motivasi Perawat dalam Melakukan Dokumentasi Keperawatan di RSD Idaman Kota Banjarbaru}

Hasil penelitian yang didapat sesuai pada teori yang disampaikan Sitorus dan Panjaitan (2011) yang mengatakan apabila supervisor ruangan tidak menjalankan perannya maka hubungan dalam proses asuhan keperawatan akan lemah, penurunan motivasi perawat, penurunan komitmen perawat terhadap mutu pelayanan kesehatan. Penelitian yang dilakukan oleh Setiawan (2018) menjelaskan kemampuan seorang supervisor ruangan dalam pelaksaan supervisi berpengaruh terhapat kualitas perawat. Penelitian hampir serupa yang dilakukan oleh Fazriannor (2018) menjelaskan bahwa peran supervisor sangat berpengaruh untuk meningkatkan kinerja perawat. Supervisor dapat meningkatkan kinerja atau motivasi perawat dengan memberikan bimbingan, arahan, motivasi, 
pelatihan, serta rencanarencana kegiatan supervisi kepada perawat. Namun, Suarli (2009) menjelaskan bahwa peran supervisor yang kurang tidak mempengaruhi motivasi dalam pendokumentasian, pengalaman nyata dan rutin dilakukan perawat yang dapat mebentuk perawat melaksanakan dokumentasi keperawatan.

\section{KESIMPULAN}

Terdapat hubungan yang signifikan antara peran kepala ruangan dengan motivasi perawat dalam melakukan dokumentasi keperawatan di RSD Idaman Kota Banjarbaru dengan nilai p-value 0,000 dengan kekuatan hubungan 0,645 (kuat). Terdapat hubungan yang signifikan antara peran supervisor ruangan dengan motivasi perawat dalam melakukan dokumentasi keperawatan di RSD Idaman Kota Banjarbaru dengan nilai p-value 0,000 dengan kekuatan hubungan 0,500 (sedang). Peran kepala ruangan dengan motivasi perawat dalam dokumentasi keperawatan lebih kuat jika dibandingkan dengan peran supervisor, hal tersebut dapat dilihat dari hasil yang didapat pada kekuatan hubungan kepala ruangan (kuat) supervisor ruangan (sedang).

Sebaiknya peran kepala ruangan dan supervisor ruangan terus ditingkatkan agar motivasi perawat dalam pendokumentasian juga akan meningkat serta rumah sakit sebagai tempat pelayanan kesehatan hendaknya selalu berperan agar kepala ruangan dan supervisor ruangan tetap lebih ditekankan untuk menjalankan perannya sehingga dapat meningkatkan motivasi perawat diruangan.

Bagi peneliti berikutnya dapat melanjutkan penelitian ini, yaitu menambahkan penelitian hingga analisis multivariat dengan menghubungkan karakteristik perawat dengan motivasi perawat.

\section{DAFTAR PUSTAKA}

Baljoon, R. Et. (2018). Nurses work motivation and the factors affecting it: A scoping review. International Journal of Nursing \& Clinical Practices, 5, 277.

Bara, M., \& Suryati, B. (2014). Hubungan motivasi perawat dengan pelaksanaan pendokumentasian asuhan keperawatan di Ruang Rawat Inap RSUD Pasar Rebo. Jurnal Health Quality, 5(1).

Fazrinnor., Pertiwiwati, E., Rizany, I. (2018). Pelaksanaan supervisi oleh supervisor dengan penerapan patient safety. Skripsi. Fakultas kedokteran program studi ilmu keperawatan universitas lambung mangkurat.

Gitosudarmo. (2012). Perilaku keorganisasian. Yogyakarta: BPFE

Green, D., \& Thomas, D. (2008). Interdisciplinary collaboration and electronic medical record. Pediatr Nurs, 34(3), 225-7.

Hasniah, dkk. (2013). Hubungan motivasi kerja dengan kinerja perawat di rsud salewang maros. Skripsi. Universitas Hasanudin Makasar.

Hoonakker, P.Et. (2013). Motivation and job satisfaction of tele-icu nurses. Journal Of Critical Care, 28 (3), 13-21.

Kamanzi, J., \& Nkosi, Z. (2011). Motivation levels among nurses working at butare university teaching hospital in rwanda. Africa Journal of Nursing and midwifery, 13 (2),119-1321.

Marquis., \& Huston. (2010). Kepemimpinan dan manajemen keperawatan teori dan aplikasi edisi 4. Jakarta: EGC.

Nivalinda, D. (2013). Pengaruh motivasi perawat dan gaya kepemimpinan kepala ruang terhadap penerapan budaya keselamatan pasien oleh 
perawat pelaksana pada rumah sakit pemerintah di semarang. Jurnal Managemen Keperawatan, 1(2), 138145.

Purnomo, M., \& Noor, C.K. (2016). Hubungan antara supervisi kepala ruangan dengan kelengkapan dokumentasi keperawatan di ruang rawat inap rsu pku muhammadiyah gubug. University Research Coloquim, 240-9189.

Rizany, I., Hariyati, R., Handayani, H. (2018). Factors that affect the development of nurses competencies: A systematic review. Envermeria Clinica, 154-157.

Robbins,S.P. (2015). Perilaku organisasi. Jakarta: Salemba Empat.

Setiawan, H. Dkk. (2018). Supervisi klinis model proctor dalam peningkatan kualitas perawatan selama prosedur intravena. Dunia Keperawatan, 6(2), 123-133.

Sitorus, R., \& Panjaitan, R. (2011). Manajemen keperawatan di ruang rawat. Jakarta: Sagung Seto

Suara, M. (2010), Konsep dasar keperawatan. Jakarta: Trans Info Media.

Suarli, S., \& Bachtiar. (2009). Manajemen keperawatan dengan pendekatan praktik. Jakarta: Erlangga.

Triwibowo. (2013). Manajemen pelayanan keperawatan di rumah sakit. Jakarta: TIM

Wahyuni, S. (2007). Analisis kompetensi kepala ruangan dalam pelaksanaan standar manajemen pelayanan keperawatan dan pengaruhnya terhadap kinerja perawat dalam mengimplementasikan model praktik keperawatan professional di instalasi rawat inap brsud banjarnegara. Prodi Magister Ilmu Kesehatan Masyarakat Universitas Diponegoro Semarang.
Wang, F. W. H. (2010). Chart audit: Strategies to improve quality of nursing documentation. Journal for Nurses in Staff Development, 25(2), 1-6.

Warsito, B. E. (2006). Pengaruh persepsi perawat pelaksana tentang fungsi manajerial kepala ruang terhadap pelaksanaan manajemen asuhan keperawatan di ruang rawat inap rsjd $d r$. amino gondogutomo semarang. Prodi Magister Ilmu Kesehatan Masyarakat Universitas Diponegoro Semarang.

Yanti, R.I., \& Bambang, E.W. (2013). Hubungan karakteristik perawat, motivasi, dan supervisi dengan kualitas dokumentasi proses asuhan keperawatan. Jurnal Managemen Keperawatan, 1(2) 107-114. 


\section{HALAMAN INI SENGAJA DIKOSONGKAN}

